\title{
Interleukin-1 receptor blockade in perinatal brain injury
}

\author{
Jason M. Rosenzweig ${ }^{1}$, Jun Lei ${ }^{1}$ and Irina Burd ${ }^{1,2,3}$ * \\ 1 Department of Gynecology and Obstetrics, Integrated Research Center for Fetal Medicine, Johns Hopkins University School of Medicine, Baltimore, MD, USA \\ ${ }^{2}$ Department of Neuroscience, Kennedy Krieger Institute, Baltimore, MD, USA \\ ${ }^{3}$ Department of Neurology, Johns Hopkins University School of Medicine, Baltimore, MD, USA
}

Edited by:

Maged Costantine, University of Texas Medical Branch, USA

Reviewed by:

Laura Haneline, Indiana University

School of Medicine, USA

Sunil K. Jain, University of Texas

Medical Branch, USA

Antonio Saad, University of Texas

Medical Branch, USA

*Correspondence:

Irina Burd, Department of

Gynecology and Obstetrics,

Integrated Research Center for Fetal

Medicine, Johns Hopkins University

Hospital, Phipps 228, 600 North Wolfe

Street, Baltimore, MD 21287, USA

e-mail: iburd@jhmi.edu
Interleukin-1 (IL-1) is a potent inflammatory cytokine that can be produced by a variety of cell types throughout the body. While IL-1 is a central mediator of inflammation and response to infection, the role of IL-1 signaling in adult and pediatric brain injury is becoming increasingly clear. Although the mechanisms of IL-1 expression are largely understood, the downstream effects and contributions to excitotoxicity and oxidative stress are poorly defined. Here, we present a review of mechanisms of IL-1 signaling with a focus on the role of IL-1 in perinatal brain injury. We highlight research models of perinatal brain injury and the use of interleukin-1 receptor antagonist (IL-1RA) as an agent of therapeutic potential in preventing perinatal brain injury due to exposure to inflammation.

Keywords: IL-1, rIL-RA, perinatal brain injury, IL-1beta, Kineret

\section{INTRODUCTION}

Interleukin-1 (IL-1) is the name given to two cytokine peptides, IL- $1 \alpha$ and IL- $1 \beta$, that bind and activate the IL- 1 receptor (IL1R). IL-1 was first called endogenous pyrogen and described as a protein isolated from polymorphonuclear leukocytes, that, when injected into humans or animals, causes fever $(1,2)$. IL-1 is a pro-inflammatory cytokine that mediates the immune response to infection and inflammation and influences a broad range of physiologic activity that includes acute-phase response gene expression, $\mathrm{T}$ and $\mathrm{B}$ lymphocyte stimulation, cell survival, glial activation, fever, hypotension, and leukopenia (3-6).

Mounting evidence suggests that IL-1 signaling plays a central role in mediating chronic and acute brain injury in both adult and pediatric populations. IL-1 receptor antagonist (IL-1RA) is an endogenous inhibitor of IL-1 signaling and recombinant IL-1RA is widely used in adults for treatment of autoimmune and inflammatory diseases such as rheumatoid arthritis and inflammatory bowel disease (5). There is emerging evidence that perinatal administration of IL-1RA may confer neuroprotective effects during births at high risk for brain injury $(7,8)$. Here, we offer a review of IL- 1 and the therapeutic potential of IL-1RA in preventing brain injury in neonates following exposure to inflammation [either intrauterine inflammation preceding preterm birth, chorioamnionitis, or birth following hypoxia-ischemia (HI)].

\section{IL-1 RECEPTOR}

The IL-1R is comprised of two membrane proteins, IL-1R1 and IL-1R accessory protein (IL-1RAcP), and binds IL- $1 \alpha$, IL$1 \beta$, IL-1RA, and IL-38. IL-1R1 and IL-1RAcP contain an intracellular Toll/interleukin-1 receptor (TIR) homology domain that recruits myeloid differentiation primary response protein
88 (MyD88) upon receptor heterodimerization (4, 9). MyD88, an adapter protein, recruits the IL-1R associated kinase 4 (IRAK4), which initiates a signaling cascade by phosphorylating and activating IRAK1, which, in turn, activates and recruits TRAF6 to the IL-1R complex. TRAF6 mediates signaling through two pathways. One pathway leads to the activation of the transcription factor NFKB through the activation of TAB2 and TAK1. The other pathway leads to the activation of the c-jun/c-fos heterodimeric activating protein 1 (AP-1) transcription factor complex through the MAPK/JNK pathway. NFאB and AP-1 activation drives expression of the pro-inflammatory genes TNF- $\alpha$, IL- 6 , and IL-1, generating an acute-phase response $(10,11)$.

A decoy receptor made up of IL-1R2 and IL-1RAcP also binds IL-1 $\beta$ but IL-1R2 lacks an intracellular activation domain (12). IL$1 \alpha$ and IL- $1 \beta$ bind IL-1R2 with much greater affinity than IL-1R1. The difference in affinity for the decoy receptor effectively creates a cytokine trap that neutralizes free IL-1 without inflammatory signaling (13). Additionally, an endogenous receptor antagonist, discussed in greater detail below, has a much lower affinity for ILR2. Together, the decoy receptor and antagonist provide a potent mechanism of regulating IL-1 signaling.

\section{IL-1 $\alpha$ AND IL-1 $\beta$}

Both IL- $1 \alpha$ and IL- $1 \beta$ transcripts are translated into precursor peptides. However, while pro-IL- $1 \beta$ requires proteolytic cleavage to generate the mature, active form of the cytokine, pro-IL- $\alpha$ is functionally active. Thus, IL- $1 \alpha$, which is expressed in epithelial cells of the gastrointestinal tract, kidney, liver, lung, endothelial cells, and astrocytes, rapidly initiates inflammatory responses when released by necrotic cell death, as occurs following ischemic events. 
IL- $1 \beta$ is expressed in hematopoietic cells, including macrophages, dendritic cells, monocytes, and microglia, and in endothelial cells. Expression of IL-1 $\beta$ is triggered by Toll-like receptor 4 (TLR4) signaling, IL- 6 signaling, or by IL- $1 \beta$ itself. As many cell types express the IL-1R, IL-1 signaling can be paracrine or autocrine. The production and release of IL- $1 \beta$ is highly regulated by cells. TLR signaling is required for the expression and translation of pro-IL- $1 \beta$. Maturation of IL- $1 \beta$ requires cleavage of pro-IL- $1 \beta$ by Caspase 1. Caspase 1 activity is regulated by the NLRP3 inflammasome. The inflammasome can be activated by numerous stimuli, including pathogen associate molecular patterns (PAMPS), external ATP and glucose, and molecules that signal of stress or danger $(14,15)$.

\section{IL-1 RECEPTOR ANTAGONIST}

The IL-1 receptor antagonist (IL-1RA) is an endogenous ligand that binds the IL-1R but does not recruit the IL-1RAcP, thereby preventing activation of the receptor (Figure 1). IL-1RA also has a higher affinity for the IL-1R than IL- $1 \alpha$ or IL- $1 \beta$ and serves to limit pro-inflammatory IL-1 signaling by blocking binding of the active cytokines (16). Deficiencies in IL-1RA result in a reduction of regulatory function and can result in severe inflammation and autoinflammatory disorders such as arthritis, vasculitis, and skin lesions in humans (17-19). IL-1RA knockout mice develop similar phenotypes to those seen in human disease, including arthropathy and arterial inflammation (20-22).

IL-1RA, IL- $1 \alpha$, and IL- $1 \beta$ have been shown to cross the bloodbrain barrier by a saturable mechanism (23). In rat models of stroke, rIL-RA, delivered subcutaneously or intravenously, can reach therapeutic concentrations in the cerebrospinal fluid within

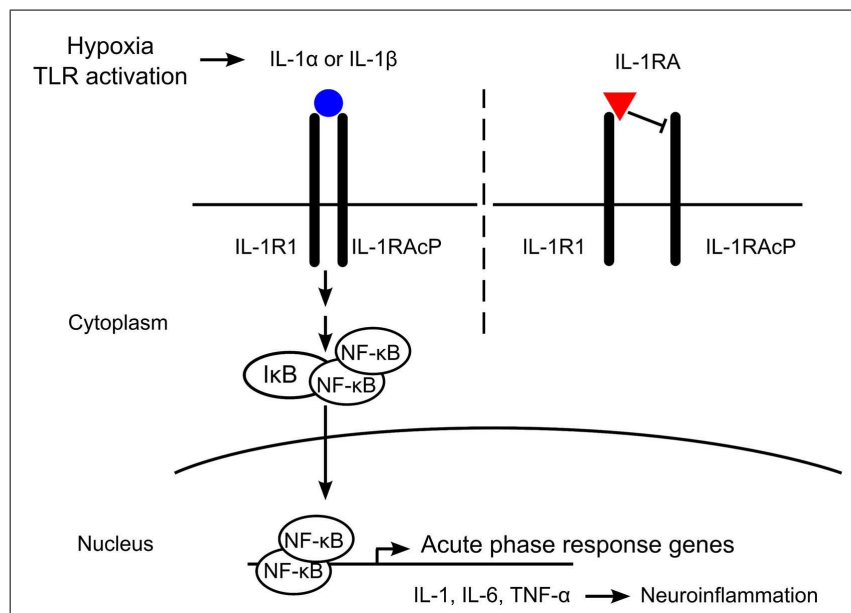

FIGURE 1 | Mechanism of interleukin-1 (IL-1) receptor antagonist (IL-1RA) blockade. IL-1 is produced in response to hypoxia or Toll-like receptor (TLR) activation. The IL-1 receptor (IL-1R) is comprised of an IL-1R1 subunit and an IL-1R accessory protein (IL-1RAcP). IL-1RA binds IL-1R1 with a higher affinity than IL-1 $\alpha$ or IL-1 $\beta$, but does not recruit IL-1RAcP. Without heterodimerization of the IL-1 receptor complex, no signaling occurs. Binding of IL-1 $\alpha$ or IL-1 $\beta$ to IL-1R1 recruits IL-1RAcP and intracellular signaling is initiated, leading to the expression of acute-phase response genes such as IL-1, interleukin-6 (IL-6), and tumor necrosis factor-alpha (TNF- $\alpha$ ). In the brain, these pro-inflammatory cytokines induce neuroinflammation, including neuronal injury and astrogliosis.
$45 \min (24,25)$. While the placenta can secrete IL-RA in response to lipopolysaccharide, to date, no studies have addressed placental transfer of rIL-1RA (26). Placental perfusion studies have found that several cytokines, including IL- $1 \beta$, TNF- $\alpha$, and IL-6, do not cross the placenta and this may hold true for rIL-1RA (27-29). Pharmacokinetic studies are warranted to determine the potential efficacy of maternally administered rIL-1RA in the setting of preterm birth. In considering possible future clinical applications, rIL-1RA may need to be delivered via amniocentesis if placental transfer is insufficient to generate therapeutic doses in the fetal compartment. With future advances and knowledge of molecular action of IL-1RA, we speculate that small molecules may be designed that will mimic IL-1RA activity and would be able to cross the placenta.

\section{CLINICAL TRIALS WITH IL-1RA}

In 1993, Amgen introduced the first drug targeting IL-1 signaling, a recombinant IL-1RA (rIL-1RA), Anakinra (Kineret). rIL-1RA is produced in E. coli and was approved by the FDA for treatment of rheumatoid arthritis in 2001. In 2012, rILRA was approved for treatment of neonatal-onset multisystem inflammatory disease (NOMID). Five randomized, double-blind, placebo-controlled trials that included over 3000 patients were conducted (30-34). Mertens and Singh offer a critical review of the rIL-1RA clinical trials (35). Briefly, the trials found rIL1RA to be significantly more effective than placebo in improving outcomes with no difference in adverse events, deaths, and study withdrawals.

Interest in recombinant rIL-1RA therapy for additional diseases continues, and at this time there are 21 ongoing clinical trials to treat a range of diseases including diabetes, breast cancer, chronic fatigue, and heart failure (Table 1). Recent mechanistic studies have reported that rIL-1RA has neuroprotective effects in rodent models of perinatal brain injury $(7,8,24,25)$.

\section{IL-1RA IN BRAIN INJURY}

Many antenatal, perinatal, or postnatal factors, whether genetic or environmental, can lead to postnatal brain injury. Chronic events prior to parturition may be of greater importance than acute events, as the chronic conditions may be overlooked until postnatal clinical symptoms are evident. Additionally, the timing of the insult influences the nature of the brain injury. Preterm infants are more likely to suffer from intraventricular hemorrhage and periventricular leukomalacia, while term infants experience focal ischemia, injury to basal ganglia, and subcortical hemorrhage (36).

Pathogen-induced inflammation and/or HI are the major insults resulting in postnatal neurological impairment through the release of inflammatory mediators, such as members of the IL-1 family (37-43). Human neuropathological studies and experimental animal models of postnatal brain injury reveal that proinflammatory cytokines, especially IL- $1 \beta$, are implicated in the cascade leading to brain damage at different developmental stages (41, 44-50). Therefore, postnatal systemic administration of IL1RA may be a potential therapeutic intervention of postnatal brain injury $(7,51)$. 
Table 1 | Ongoing rIL-1RA clinical trials.

\begin{tabular}{|c|c|c|c|}
\hline Study title & Phase & Primary outcome measures & Anakinra dose \\
\hline $\begin{array}{l}\text { Anakinra combined with chemotherapy and } \\
\text { dendritic cell vaccine to treat breast cancer }\end{array}$ & $1 / 2$ & $\begin{array}{l}\text { Safety of DC vaccine combined with chemotherapy, and } \\
\text { DC vaccine combined with chemotherapy and anakinra }\end{array}$ & $\begin{array}{l}100 \mathrm{mg} / \text { day } \\
\text { subcutaneous }\end{array}$ \\
\hline $\begin{array}{l}\text { Infants and children with coronary artery } \\
\text { abnormalities in acute Kawasaki disease }\end{array}$ & $1 / 2$ & Safety of a 6-week course of anakinra & $\begin{array}{l}2 \mathrm{mg} / \mathrm{kg} / \text { day } \\
4 \mathrm{mg} / \mathrm{kg} / \text { day }\end{array}$ \\
\hline $\begin{array}{l}\text { Adult patients with colchicine-resistant familial } \\
\text { Mediterranean fever }\end{array}$ & 3 & $\begin{array}{l}\text { Number of patients with less than a mean of one FMF } \\
\text { attack per month }\end{array}$ & $\begin{array}{l}100 \mathrm{mg} / \text { day } \\
\text { subcutaneous }\end{array}$ \\
\hline $\begin{array}{l}\text { Safety and blood immune cell study of anakinra } \\
\text { in metastatic breast cancer patients }\end{array}$ & 1 & Safety - adverse events in participants & $\begin{array}{l}100 \mathrm{mg} / \text { day } \\
\text { subcutaneous }\end{array}$ \\
\hline $\begin{array}{l}\text { Anakinra or denosumab and everolimus in } \\
\text { advanced cancer }\end{array}$ & 1 & Maximum tolerated dose (MTD) & $\begin{array}{l}100 \mathrm{mg} / \text { day } \\
\text { subcutaneous }\end{array}$ \\
\hline $\begin{array}{l}\text { Efficacy study of anakinra, pentoxifylline, and } \\
\text { zinc compared to methylprednisolone in severe } \\
\text { acute alcoholic hepatitis }\end{array}$ & $2 / 3$ & Death|MELD score & $\begin{array}{l}100 \mathrm{mg} / \text { day } \\
\text { subcutaneous }\end{array}$ \\
\hline $\begin{array}{l}\text { Safety and tolerability of anakinra in combination } \\
\text { with riluzol in amyotrophic lateral sclerosis }\end{array}$ & 2 & $\begin{array}{l}\text { Number and severity of adverse events, pathological } \\
\text { laboratory parameters }\end{array}$ & $\begin{array}{l}100 \mathrm{mg} / \text { day } \\
\text { subcutaneous }\end{array}$ \\
\hline $\begin{array}{l}\text { IL-1 blockade in acute myocardial infarction } \\
\text { (VCU-ART3) }\end{array}$ & $2 / 3$ & Acute response (CRP levels) & $\begin{array}{l}100 \mathrm{mg} / \text { day } \\
\text { subcutaneous }\end{array}$ \\
\hline $\begin{array}{l}\text { Study evaluating the influence of LV5FU2 } \\
\text { bevacizumab plus anakinra association on } \\
\text { metastatic colorectal cancer }\end{array}$ & 2 & $\begin{array}{l}\text { Response rate after } 2 \text { months in patients with colorectal } \\
\text { cancer with liver metastases treated with anakinra and } \\
\text { LV5FU2/bevacizumab }\end{array}$ & $\begin{array}{l}100 \mathrm{mg} / \text { day } \\
\text { subcutaneous }\end{array}$ \\
\hline $\begin{array}{l}\text { Evaluation of the safety of anakinra plus } \\
\text { standard chemotherapy }\end{array}$ & 1 & $\begin{array}{l}\text { The number of participants with serious adverse events } \\
\text { and adverse events }\end{array}$ & $\begin{array}{l}100 \mathrm{mg} / \text { day } \\
\text { subcutaneous }\end{array}$ \\
\hline $\begin{array}{l}\text { IL-1 blockade in acute heart failure (anakinra } \\
\text { ADHF) }\end{array}$ & $2 / 3$ & $\mathrm{C}$ reactive protein & $\begin{array}{l}200 \mathrm{mg} / \text { day for } 3 \text { days } \\
\text { (high dose) } \\
100 \mathrm{mg} / \text { day (standard } \\
\text { dose) }\end{array}$ \\
\hline $\begin{array}{l}\text { Interleukin-1 blockade in recently } \\
\text { decompensated heart failure }\end{array}$ & $2 / 3$ & $\begin{array}{l}\text { Placebo-corrected interval changes in peak VO2 and } \\
\text { VENCO2 slope }\end{array}$ & $\begin{array}{l}100 \mathrm{mg} / \text { day } \\
\text { subcutaneous }\end{array}$ \\
\hline Inflammatory pustular skin diseases & 2 & Obtain an estimate of the response rate to treatment & $\begin{array}{l}\text { 100-300 mg/day } \\
\text { subcutaneous }\end{array}$ \\
\hline $\begin{array}{l}\text { Effect of anakinra on insulin sensitivity in type } 1 \\
\text { diabetes mellitus }\end{array}$ & 2 & $\begin{array}{l}\text { Insulin sensitivity as determined by euglycemic } \\
\text { hyperinsulinemic clamp }\end{array}$ & $\begin{array}{l}100 \mathrm{mg} / \text { day } \\
\text { subcutaneous }\end{array}$ \\
\hline $\begin{array}{l}\text { Gene expression profiling in PBMCs as a tool } \\
\text { for prediction of anakinra responsiveness in } \\
\text { rheumatoid arthritis }\end{array}$ & 4 & Observational & $\begin{array}{l}100 \mathrm{mg} / \text { day } \\
\text { subcutaneous }\end{array}$ \\
\hline Role of interleukin-1 in postprandial fatigue & 1 & Postprandial fatigue & 100 mg subcutaneous \\
\hline $\begin{array}{l}\text { Immunomodulation, IL-1 inhibition, and } \\
\text { postoperative incisional pain }\end{array}$ & $\mathrm{N} / \mathrm{A}^{\mathrm{a}}$ & $\begin{array}{l}\text { Concentration levels of inflammatory mediators (IL-1, } \\
\text { IL-6, IL-8, and TNF- } \alpha \text { ) present in human wounds following } \\
\text { surgery with and without the use of anakinra }\end{array}$ & $\mathrm{N} / \mathrm{A}^{\mathrm{a}}$ \\
\hline $\begin{array}{l}\text { Cytokine inhibition in chronic fatigue syndrome } \\
\text { patients }\end{array}$ & $2 / 3$ & CIS (checklist individual strength, compared to baseline) & $\begin{array}{l}100 \mathrm{mg} / \text { day } \\
\text { subcutaneous }\end{array}$ \\
\hline $\begin{array}{l}\text { A dose-block randomized, placebo controlled } \\
\text { (double-blind), active controlled(open-label), } \\
\text { dose-escalation study }\end{array}$ & 1 & $\begin{array}{l}\text { Tolerability, pharmacokinetics of HL2351, } \\
\text { Immunogenicity of HL2351, Tolerability, } \\
\text { pharmacokinetics, and pharmacodynamics of HL2351 in } \\
\text { comparison with kineret (anakinra), IL-6 inhibition assay }\end{array}$ & $\begin{array}{l}100 \mathrm{mg} / \text { day } \\
\text { subcutaneous }\end{array}$ \\
\hline $\begin{array}{l}\text { Anti-IL-1 treatment in children DKA at diagnosis } \\
\text { of type } 1 \text { diabetes }\end{array}$ & 2 & Number of adverse events & $\begin{array}{l}2 \mathrm{mg} / \mathrm{kg} \text { bolus followed } \\
\text { by } 2 \mathrm{mg} / \mathrm{kg} / \mathrm{h} \text { infusion }\end{array}$ \\
\hline Interleukin-1 blockade in HF with preserved EF & 2 & Aerobic exercise capacity, ventilatory efficiency & $\begin{array}{l}100 \mathrm{mg} / \text { day } \\
\text { subcutaneous }\end{array}$ \\
\hline
\end{tabular}

${ }^{a}$ Data not available. 


\section{IL-1RA AND PATHOGENIC MODELS OF POSTNATAL BRAIN INJURY}

Several models of inflammatory postnatal brain injury have been developed in different species, including mouse (52-56), rat (5759), rabbit (60, 61), dog (62), and others (63). Rodent models are most widely used due to ease of use and relatively short reproductive cycle. Administration of pathogens, such as virus (52), bacteria (64), pathogenic infectious components (57,61), and proinflammatory cytokines $(46,65)$ varies widely between models in timing, from prenatal to postnatal stage, and route of delivery, whether intranasal $(52,66)$, intravenous $(67)$, intrauterine $(68$, 69), intraperitoneal (59), or intracerebral injection (70).

IL-1RA has been shown to be neuroprotective (71-73) in animal models of traumatic brain injury and excitotoxicity in vivo and in vitro, in which IL-1 $\beta$ exerts a dominant role pathologically. In rodent models of postnatal brain injury, the elevation of IL- $1 \beta$ and other pro-inflammatory cytokines was observed $(69,74,75)$, indicating the importance of the IL- $1 \beta$ signaling pathway in postnatal brain injury. Leitner et al. applied rIL-1RA systemically at embryonic day $15,30 \mathrm{~min}$ prior to administration of intrauterine injection of lipopolysaccharide. They found rIL-1RA improved fetal cortical neuronal injury without affecting the rate of preterm birth. This might be via the blockade of neuronal nitric oxide synthase (8). Furthermore, Girard et al. administrated a low dose of rIL-1RA to pups in a systemic inflammatory animal model and a hypoxic-ischemia model postnatally $(7,76)$. This treatment preserved motor function and exploratory behavior. Neuroprotective effects were evident by increased neural stem cell populations, prevention of myelin loss, and decreased gliosis. This study provides a potential candidate for postnatal treatment of brain injury, especially in the earliest days of life in the term infant. Savard et al. used systemic infection-inflammation combined with $\mathrm{HI}$ in a rat model at postnatal day 12, which exerted a synergistic detrimental effect on rat brain, leading to a peculiar pattern of parasagittal corticalsubcortical infarcts mimicking those in the human full-term newborn with subsequent severe neurodevelopmental impairments. rIL-1RA administration reduced the extent of brain lesions by MRI observation (50).

\section{IL-1RA AND HYPOXIA-ISCHEMIA ASSOCIATED POSTNATAL BRAIN INJURY MODEL}

Hypoxia-ischemia is another common cause of postnatal brain injury. The most widely used HI model is the Vannucci model, which combines permanent unilateral ligation of the carotid artery in 7-day-old rat pups, along with exposure to hypoxia (7780). Increased expression of pro-inflammatory cytokines including IL-1 $\beta$ is associated with HI-induced postnatal brain injury (81-83).

Experimental administration of rIL-1RA has been demonstrated to reduce HI-induced postnatal brain injury (84-86). Martin et al. injected rIL-1RA subcutaneously in a postnatal rat $\mathrm{HI}$ model and found prior to or after HI, rIL-1RA ameliorated the ischemia damage as measured by hemisphere dry weights and prevented neuronal loss in the striatum (87). Hu et al. injected $2 \mu \mathrm{g}$ rIL-1RA intra-cerebroventricularly $2 \mathrm{~h}$ after $\mathrm{HI}$ and found a significant reduction in cell death and Caspase 3 activity. The observed increase in cytoplasmic NFKB activation and nuclear translocation of Bcl-3 $24 \mathrm{~h}$ after $\mathrm{HI}$ was also significantly attenuated by IL-1 blockade, suggesting that HI-induced IL-1 activation is via both the NFKB activation and the nuclear translocation of Bcl-3 (88).

Though a rapidly expanding body of evidence indicates that rIL-1RA is a promising therapeutic for postnatal brain injury, the specific signaling mechanisms triggered by rIL-1RA responsible for the effects are still not fully known. A number of drawbacks of rIL-1RA limit its broader use; these include injection site reactions $(89,90)$, broad immunosuppression (90), and high costs. Trials to test safety in a pediatric population are sorely needed as a lack of efficacy and safety data limits the adoption of rIL-1RA for perinatal brain injury.

\section{CONCLUDING REMARIS}

During infection and inflammation, the potent effects of IL-1 signaling can lead to devastating tissue damage with long-lasting effects. Therapies that block IL-1 signaling have been successful in reducing negative outcomes in autoinflammatory diseases in adults for over a decade now. Exciting research in the area of neonatal encephalopathy suggests that the benefits of IL-1 blockade in reducing injury in autoinflammatory diseases may be extended to neonatal brain injury and offer much needed neuroprotection for a population with limited effective treatment options.

Neonatal encephalopathy affects up to $1 \%$ of live births (9193) and the causes can vary from hypoxic-ischemic events to intrauterine inflammation $(37,38,40-43)$. Treatment options are limited and the current standard of care prescribes therapeutic hypothermia (94). Hypothermia, however, does not confer complete neuroprotection and as many as $50 \%$ of treated neonates will experience moderate to severe neurologic disability (95). Common processes that contribute to neuronal injury, including oxidative stress, apoptosis, inflammation, and excitotoxicity, are increasingly the targets of emerging therapies for neonatal encephalopathy.

As a Class B drug, rIL-1RA is approved for use in pregnant women and may be offered in the future as a perinatal intervention to prevent perinatal brain injury due to neonatal encephalopathy or due to exposure to intrauterine inflammation. However, rIL-1RA is not approved for the treatment or prevention of perinatal brain injury, and further studies are needed to determine its safety and efficacy. At this time, little is known in regards to the importance of IL-1 in brain formation or the development of the immature immune system; therefore, further evaluation of this molecule is necessary to establish appropriate safe timing of its administration for variety of etiologies of perinatal brain injury. Furthermore, no studies have yet been conducted to assess the efficacy of rIL-1RA in combination with other therapies, such as hypothermia, although other combination therapies (hypothermia and erythropoietin) have shown promise in rodent models $(96,97)$. Mechanistic studies of r-IL1RA, as we are conducting, are ongoing to evaluate maternal-fetal transfer and developmental effects in animal models.

\section{REFERENCES}

1. Beeson PB. Temperature-elevating effect of a substance obtained from polymorphonuclear leucocytes. J Clin Invest (1948) 27(4):524. 
2. Atkins E. Pathogenesis of fever. Physiol Rev (1960) 40:580-646.

3. Dinarello CA. Interleukin-1 and interleukin-1 antagonism. Blood (1991) 77(8):1627-52.

4. Sims JE, Smith DE. The IL-1 family: regulators of immunity. Nat Rev Immunol (2010) 10(2):89-102. doi:10.1038/nri2691

5. Dinarello CA, Simon A, van der Meer JW. Treating inflammation by blocking interleukin-1 in a broad spectrum of diseases. Nat Rev Drug Discov (2012) 11(8):633-52. doi:10.1038/nrd3800

6. Garlanda C, Dinarello CA, Mantovani A. The interleukin-1 family: back to the future. Immunity (2013) 39(6):1003-18. doi:10.1016/j.immuni.2013.11.010

7. Girard S, Sebire H, Brochu ME, Briota S, Sarret P, Sebire G. Postnatal administration of IL-1Ra exerts neuroprotective effects following perinatal inflammation and/or hypoxic-ischemic injuries. Brain Behav Immun (2012) 26(8):1331-9. doi:10.1016/j.bbi.2012.09.001

8. Leitner K, Al Shammary M, McLane M, Johnston MV, Elovitz MA, Burd I. IL1 receptor blockade prevents fetal cortical brain injury but not preterm birth in a mouse model of inflammation-induced preterm birth and perinatal brain injury. Am J Reprod Immunol (2014) 71(5):418-26. doi:10.1111/aji.12216

9. Dunne A, O’Neill LA. The interleukin-1 receptor/Toll-like receptor superfamily: signal transduction during inflammation and host defense. Sci STKE (2003) 2003(171):re3. doi:10.1126/stke.2003.171.re3

10. Watters TM, Kenny EF, O'Neill LA. Structure, function and regulation of the Toll/IL-1 receptor adaptor proteins. Immunol Cell Biol (2007) 85(6):411-9. doi:10.1038/sj.icb.7100095

11. Casanova JL, Abel L, Quintana-Murci L. Human TLRs and IL-1Rs in host defense: natural insights from evolutionary, epidemiological, and clinical genetics. Annu Rev Immunol (2011) 29:447-91. doi:10.1146/annurev-immunol030409-101335

12. McMahan CJ, Slack JL, Mosley B, Cosman D, Lupton SD, Brunton LL, et al. A novel IL-1 receptor, cloned from B cells by mammalian expression, is expressed in many cell types. EMBO J (1991) 10(10):2821-32.

13. Hannum CH, Wilcox CJ, Arend WP, Joslin FG, Dripps DJ, Heimdal PL, et al. Interleukin-1 receptor antagonist activity of a human interleukin-1 inhibitor. Nature (1990) 343(6256):336-40. doi:10.1038/343336a0

14. Mariathasan S, Newton K, Monack DM, Vucic D, French DM, Lee WP, et al. Differential activation of the inflammasome by caspase-1 adaptors ASC and Ipaf. Nature (2004) 430(6996):213-8. doi:10.1038/nature02664

15. Tschopp J, Schroder K. NLRP3 inflammasome activation: the convergence of multiple signalling pathways on ROS production? Nat Rev Immunol (2010) 10(3):210-5. doi:10.1038/nri2725

16. Dinarello CA. Anti-inflammatory agents: present and future. Cell (2010) 140(6):935-50. doi:10.1016/j.cell.2010.02.043

17. Aksentijevich I, Masters SL, Ferguson PJ, Dancey P, Frenkel J, van RoyenKerkhoff A, et al. An autoinflammatory disease with deficiency of the interleukin-1-receptor antagonist. N Engl J Med (2009) 360(23):2426-37. doi:10.1056/NEJMoa0807865

18. Gabay C, Palmer G. Mutations in the IL1RN locus lead to autoinflammation. Nat Rev Rheumatol (2009) 5(9):480-2. doi:10.1038/nrrheum.2009.177

19. Reddy S, Jia S, Geoffrey R, Lorier R, Suchi M, Broeckel U, et al. An autoinflammatory disease due to homozygous deletion of the IL1RN locus. N Engl J Med (2009) 360(23):2438-44. doi:10.1056/NEJMoa0809568

20. Horai R, Asano M, Sudo K, Kanuka H, Suzuki M, Nishihara M, et al. Production of mice deficient in genes for interleukin (IL)-1alpha, IL-1beta, ILlalpha/beta, and IL-1 receptor antagonist shows that IL-1beta is crucial in turpentine-induced fever development and glucocorticoid secretion. J Exp Med (1998) 187(9):1463-75. doi:10.1084/jem.187.9.1463

21. Horai R, Saijo S, Tanioka H, Nakae S, Sudo K, Okahara A, et al. Development of chronic inflammatory arthropathy resembling rheumatoid arthritis in interleukin 1 receptor antagonist-deficient mice. J Exp Med (2000) 191(2):313-20. doi:10.1084/jem.191.2.313

22. Nicklin MJ, Hughes DE, Barton JL, Ure JM, Duff GW. Arterial inflammation in mice lacking the interleukin 1 receptor antagonist gene. J Exp Med (2000) 191(2):303-12. doi:10.1084/jem.191.2.303

23. Banks WA, Kastin AJ, Broadwell RD. Passage of cytokines across the blood-brain barrier. Neuroimmunomodulation (1995) 2(4):241-8. doi:10.1159/000096887

24. Greenhalgh AD, Galea J, Denes A, Tyrrell PJ, Rothwell NJ. Rapid brain penetration of interleukin-1 receptor antagonist in rat cerebral ischaemia: pharmacokinetics, distribution, protection. Br J Pharmacol (2010) 160(1):153-9. doi:10.1111/j.1476-5381.2010.00684.x
25. Galea J, Ogungbenro K, Hulme S, Greenhalgh A, Aarons L, Scarth S, et al. Intravenous anakinra can achieve experimentally effective concentrations in the central nervous system within a therapeutic time window: results of a dose-ranging study. J Cereb Blood Flow Metab (2011) 31(2):439-47. doi:10.1038/jcbfm.2010. 103

26. Amash A, Holcberg G, Sapir O, Huleihel M. Placental secretion of interleukin1 and interleukin-1 receptor antagonist in preeclampsia: effect of magnesium sulfate. J Interferon Cytokine Res (2012) 32(9):432-41. doi:10.1089/jir.2012.0013

27. Reisenberger K, Egarter C, Vogl S, Sternberger B, Kiss H, Husslein P. The transfer of interleukin-8 across the human placenta perfused in vitro. Obstet Gynecol (1996) 87(4):613-6. doi:10.1016/0029-7844(95)00473-4

28. Zaretsky MV, Alexander JM, Byrd W, Bawdon RE. Transfer of inflammatory cytokines across the placenta. Obstet Gynecol (2004) 103(3):546-50. doi:10.1097/01.AOG.0000114980.40445.83

29. Aaltonen R, Heikkinen T, Hakala K, Laine K, Alanen A. Transfer of proinflammatory cytokines across term placenta. Obstet Gynecol (2005) 106(4):802-7. doi:10.1097/01.AOG.0000178750.84837.ed

30. Bresnihan B, Alvaro-Gracia JM, Cobby M, Doherty M, Domljan Z, Emery P, et al. Treatment of rheumatoid arthritis with recombinant human interleukin1 receptor antagonist. Arthritis Rheum (1998) 41(12):2196-204. doi:10.1002/ 1529-0131(199812)41:12<2196::AID-ART15>3.3.CO;2-U

31. Cohen S, Hurd E, Cush J, Schiff M, Weinblatt ME, Moreland LW, et al. Treatment of rheumatoid arthritis with anakinra, a recombinant human interleukin-1 receptor antagonist, in combination with methotrexate: results of a twenty-fourweek, multicenter, randomized, double-blind, placebo-controlled trial. Arthritis Rheum (2002) 46(3):614-24. doi:10.1002/art.10103

32. Fleischmann RM, Schechtman J, Bennett R, Handel ML, Burmester GR, Tesser $\mathrm{J}$, et al. Anakinra, a recombinant human interleukin-1 receptor antagonist (r-metHuIL-1ra), in patients with rheumatoid arthritis: a large, international, multicenter, placebo-controlled trial. Arthritis Rheum (2003) 48(4):927-34. doi:10.1002/art.10870

33. Cohen SB, Moreland LW, Cush JJ, Greenwald MW, Block S, Shergy WJ, et al. A multicentre, double blind, randomised, placebo controlled trial of anakinra (Kineret), a recombinant interleukin 1 receptor antagonist, in patients with rheumatoid arthritis treated with background methotrexate. Ann Rheum Dis (2004) 63(9):1062-8. doi:10.1136/ard.2003.016014

34. Genovese MC, Cohen S, Moreland L, Lium D, Robbins S, Newmark R, et al. Combination therapy with etanercept and anakinra in the treatment of patients with rheumatoid arthritis who have been treated unsuccessfully with methotrexate. Arthritis Rheum (2004) 50(5):1412-9. doi:10.1002/art.20221

35. Mertens M, Singh JA. Anakinra for rheumatoid arthritis. Cochrane Database Syst Rev (2009) 1:CD005121. doi:10.1002/14651858.CD005121.pub3

36. Van den Broeck C, Himpens E, Vanhaesebrouck P, Calders P, Oostra A. Influence of gestational age on the type of brain injury and neuromotor outcome in high-risk neonates. Eur J Pediatr (2008) 167(9):1005-9. doi:10.1007/s00431007-0629-2

37. Schendel DE, Schuchat A, Thorsen P. Public health issues related to infection in pregnancy and cerebral palsy. Ment Retard Dev Disabil Res Rev (2002) 8(1):39-45. doi:10.1002/mrdd.10011

38. Bracci R, Buonocore G. Chorioamnionitis: a risk factor for fetal and neonatal morbidity. Biol Neonate (2003) 83(2):85-96. doi:10.1159/000067956

39. McLean C, Ferriero D. Mechanisms of hypoxic-ischemic injury in the term infant. Semin Perinatol (2004) 28(6):425-32. doi:10.1053/j.semperi.2004.10.005

40. Boksa P. Effects of prenatal infection on brain development and behavior: a review of findings from animal models. Brain Behav Immun (2010) 24(6):881-97. doi:10.1016/j.bbi.2010.03.005

41. Arrode-Bruses G, Bruses JL. Maternal immune activation by poly I:C induces expression of cytokines IL-1beta and IL-13, chemokine MCP-1 and colony stimulating factor VEGF in fetal mouse brain. J Neuroinflammation (2012) 9:83. doi:10.1186/1742-2094-9-83

42. Hagberg H, Gressens P, Mallard C. Inflammation during fetal and neonatal life: implications for neurologic and neuropsychiatric disease in children and adults. Ann Neurol (2012) 71(4):444-57. doi:10.1002/ana.22620

43. Meyer U. Developmental neuroinflammation and schizophrenia. Prog Neuropsychopharmacol Biol Psychiatry (2013) 42:20-34. doi:10.1016/j.pnpbp. 2011.11.003

44. Allan SM, Pinteaux E. The interleukin-1 system: an attractive and viable therapeutic target in neurodegenerative disease. Curr Drug Targets CNS Neurol Disord (2003) 2(5):293-302. doi:10.2174/1568007033482742 
45. Rothwell N. Interleukin-1 and neuronal injury: mechanisms, modification, and therapeutic potential. Brain Behav Immun (2003) 17(3):152-7. doi:10.1016/ S0889-1591(02)00098-3

46. Cai Z, Lin S, Pang Y, Rhodes PG. Brain injury induced by intracerebral injection of interleukin-1beta and tumor necrosis factor-alpha in the neonatal rat. Pediatr Res (2004) 56(3):377-84. doi:10.1203/01.PDR.0000134249.92944.14

47. Allan SM, Tyrrell PJ, Rothwell NJ. Interleukin-1 and neuronal injury. Nat Rev Immunol (2005) 5(8):629-40. doi:10.1038/nri1664

48. Thornton P, Pinteaux E, Gibson RM, Allan SM, Rothwell NJ. Interleukin-1induced neurotoxicity is mediated by glia and requires caspase activation and free radical release. J Neurochem (2006) 98(1):258-66. doi:10.1111/j.1471-4159. 2006.03872.x

49. Denes A, Pinteaux E, Rothwell NJ, Allan SM. Interleukin-1 and stroke: biomarker, harbinger of damage, and therapeutic target. Cerebrovasc Dis (2011) 32(6):517-27. doi:10.1159/000332205

50. Savard A, Lavoie K, Brochu ME, Grbic D, Lepage M, Gris D, et al. Involvement of neuronal IL-1beta in acquired brain lesions in a rat model of neonatal encephalopathy. J Neuroinflammation (2013) 10:110. doi:10.1186/1742-209410- 110

51. Green HF, Treacy E, Keohane AK, Sullivan AM, O'Keeffe GW, Nolan YM. A role for interleukin-1beta in determining the lineage fate of embryonic rat hippocampal neural precursor cells. Mol Cell Neurosci (2012) 49(3):311-21. doi:10.1016/j.mcn.2012.01.001

52. Fatemi SH, Emamian ES, Sidwell RW, Kist DA, Stary JM, Earle JA, et al. Human influenza viral infection in utero alters glial fibrillary acidic protein immunoreactivity in the developing brains of neonatal mice. Mol Psychiatry (2002) 7(6):633-40. doi:10.1038/sj.mp.4001046

53. Aden U, Favrais G, Plaisant F, Winerdal M, Felderhoff-Mueser U, Lampa $\mathrm{J}$, et al. Systemic inflammation sensitizes the neonatal brain to excitotoxicity through a pro-/anti-inflammatory imbalance: key role of TNFalpha pathway and protection by etanercept. Brain Behav Immun (2010) 24(5):747-58. doi:10.1016/j.bbi.2009.10.010

54. Chang EY, Zhang J, Sullivan S, Newman R, Singh I. N-acetylcysteine attenuates the maternal and fetal proinflammatory response to intrauterine LPS injection in an animal model for preterm birth and brain injury. J Matern Fetal Neonatal Med (2011) 24(5):732-40. doi:10.3109/14767058.2010.528089

55. Burd I, Balakrishnan B, Kannan S. Models of fetal brain injury, intrauterine inflammation, and preterm birth. Am J Reprod Immunol (2012) 67(4):287-94. doi:10.1111/j.1600-0897.2012.01110.x

56. Dada T, Rosenzweig JM, Al Shammary M, Firdaus W, Al Rebh S, Borbiev T, et al. Mouse model of intrauterine inflammation: sex-specific differences in longterm neurologic and immune sequelae. Brain Behav Immun (2014) 38:142-50. doi:10.1016/j.bbi.2014.01.014

57. Bell MJ, Hallenbeck JM. Effects of intrauterine inflammation on developing rat brain. J Neurosci Res (2002) 70(4):570-9. doi:10.1002/jnr.10423

58. Auvin S, Shin D, Mazarati A, Nakagawa J, Miyamoto J, Sankar R. Inflammation exacerbates seizure-induced injury in the immature brain. Epilepsia (2007) 48(Suppl 5):27-34. doi:10.1111/j.1528-1167.2007.01239.x

59. Beloosesky R, Ginsberg Y, Khatib N, Maravi N, Ross MG, Itskovitz-Eldor J, et al. Prophylactic maternal $\mathrm{N}$-acetylcysteine in rats prevents maternal inflammationinduced offspring cerebral injury shown on magnetic resonance imaging. Am J Obstet Gynecol (2013) 208(3):e211-6. doi:10.1016/j.ajog.2013.01.023

60. Hagberg H, Peebles D, Mallard C. Models of white matter injury: comparison of infectious, hypoxic-ischemic, and excitotoxic insults. Ment Retard Dev Disabil Res Rev (2002) 8(1):30-8. doi:10.1002/mrdd.10020

61. Kannan S, Saadani-Makki F, Muzik O, Chakraborty P, Mangner TJ, Janisse J, et al. Microglial activation in perinatal rabbit brain induced by intrauterine inflammation: detection with 11C-(R)-PK11195 and small-animal PET. J Nucl Med (2007) 48(6):946-54. doi:10.2967/jnumed.106.038539

62. Young RS, Hernandez MJ, Yagel SK. Selective reduction of blood flow to white matter during hypotension in newborn dogs: a possible mechanism of periventricular leukomalacia. Ann Neurol (1982) 12(5):445-8. doi:10.1002/ana. 410120506

63. Yawno T, Schuilwerve J, Moss TJ, Vosdoganes P, Westover AJ, Afandi E, et al. Human amnion epithelial cells reduce fetal brain injury in response to intrauterine inflammation. Dev Neurosci (2013) 35(2-3):272-82. doi:10.1159/000346683

64. Debillon T, Gras-Leguen C, Verielle V, Winer N, Caillon J, Roze JC, et al. Intrauterine infection induces programmed cell death in rabbit periventricular white matter. Pediatr Res (2000) 47(6):736-42. doi:10.1203/ 00006450-200006000-00009

65. Fan LW, Tien LT, Zheng B, Pang Y, Rhodes PG, Cai Z. Interleukin-1beta-induced brain injury and neurobehavioral dysfunctions in juvenile rats can be attenuated by alpha-phenyl-n-tert-butyl-nitrone. Neuroscience (2010) 168(1):240-52. doi:10.1016/j.neuroscience.2010.03.024

66. Shi L, Fatemi SH, Sidwell RW, Patterson PH. Maternal influenza infection causes marked behavioral and pharmacological changes in the offspring. $J$ Neurosci (2003) 23(1):297-302.

67. Meyer U, Feldon J, Schedlowski M, Yee BK. Immunological stress at the maternal-foetal interface: a link between neurodevelopment and adult psychopathology. Brain Behav Immun (2006) 20(4):378-88. doi:10.1016/j.bbi.2005. 11.003

68. Cai Z, Pan ZL, Pang Y, Evans OB, Rhodes PG. Cytokine induction in fetal rat brains and brain injury in neonatal rats after maternal lipopolysaccharide administration. Pediatr Res (2000) 47(1):64-72. doi:10.1203/00006450200001000-00013

69. Burd I, Brown A, Gonzalez JM, Chai J, Elovitz MA. A mouse model of term chorioamnionitis: unraveling causes of adverse neurological outcomes. Reprod Sci (2011) 18(9):900-7. doi:10.1177/1933719111398498

70. Cai Z, Fan LW, Lin S, Pang Y, Rhodes PG. Intranasal administration of insulin-like growth factor-1 protects against lipopolysaccharide-induced injury in the developing rat brain. Neuroscience (2011) 194:195-207. doi:10.1016/j. neuroscience.2011.08.003

71. Hagan P, Barks JD, Yabut M, Davidson BL, Roessler B, Silverstein FS. Adenovirusmediated over-expression of interleukin-1 receptor antagonist reduces susceptibility to excitotoxic brain injury in perinatal rats. Neuroscience (1996) 75(4):1033-45. doi:10.1016/0306-4522(96)00225-4

72. Ide CF, Scripter JL, Coltman BW, Dotson RS, Snyder DC, Jelaso A. Cellular and molecular correlates to plasticity during recovery from injury in the developing mammalian brain. Prog Brain Res (1996) 108:365-77. doi:10.1016/S00796123(08)62552-2

73. Scripter JL, Ko J, Kow K, Arimura A, Ide CF. Regulation by interleukin-1beta of formation of a line of delimiting astrocytes following prenatal trauma to the brain of the mouse. Exp Neurol (1997) 145(2 Pt 1):329-41. doi:10.1006/exnr. 1997.6470

74. Yoon BH, Romero R, Jun JK, Park KH, Park JD, Ghezzi F, et al. Amniotic fluid cytokines (interleukin-6, tumor necrosis factor-alpha, interleukin-1 beta, and interleukin-8) and the risk for the development of bronchopulmonary dysplasia. Am J Obstet Gynecol (1997) 177(4):825-30. doi:10.1016/S0002-9378(97) 70276-X

75. Kadhim H, Tabarki B, De Prez C, Sebire G. Cytokine immunoreactivity in cortical and subcortical neurons in periventricular leukomalacia: are cytokines implicated in neuronal dysfunction in cerebral palsy? Acta Neuropathol (2003) 105(3):209-16. doi:10.1007/s00401-002-0633-6

76. Girard S, Sebire G, Kadhim H. Proinflammatory orientation of the interleukin 1 system and downstream induction of matrix metalloproteinase 9 in the pathophysiology of human perinatal white matter damage. J Neuropathol Exp Neurol (2010) 69(11):1116-29. doi:10.1097/NEN.0b013e3181f971e4

77. Rice JE III, Vannucci RC, Brierley JB. The influence of immaturity on hypoxicischemic brain damage in the rat. Ann Neurol (1981) 9(2):131-41. doi:10.1002/ ana.410090206

78. Comi AM, Johnston MV, Wilson MA. Immature mouse unilateral carotid ligation model of stroke. J Child Neurol (2005) 20(12):980-3. doi:10.1177/ 08830738050200120901

79. Johnston MV, Ferriero DM, Vannucci SJ, Hagberg H. Models of cerebral palsy: which ones are best? J Child Neurol (2005) 20(12):984-7. doi:10.1177/ 08830738050200091101

80. Falahati S, Breu M, Waickman AT, Phillips AW, Arauz EJ, Snyder S, et al. Ischemiainduced neuroinflammation is associated with disrupted development of oligodendrocyte progenitors in a model of periventricular leukomalacia. Dev Neurosci (2013) 35(2-3):182-96. doi:10.1159/000346682

81. Szaflarski J, Burtrum D, Silverstein FS. Cerebral hypoxia-ischemia stimulates cytokine gene expression in perinatal rats. Stroke (1995) 26(6):1093-100. doi:10.1161/01.STR.26.6.1093

82. Silverstein FS, Barks JD, Hagan P, Liu XH, Ivacko J, Szaflarski J. Cytokines and perinatal brain injury. Neurochem Int (1997) 30(4-5):375-83. doi:10.1016/ S0197-0186(96)00072-1 
83. Carlsson Y, Leverin AL, Hedtjarn M, Wang X, Mallard C, Hagberg H. Role of mixed lineage kinase inhibition in neonatal hypoxia-ischemia. Dev Neurosci (2009) 31(5):420-6. doi:10.1159/000232560

84. Park EM, Cho BP, Volpe BT, Cruz MO, Joh TH, Cho S. Ibuprofen protects ischemia-induced neuronal injury via up-regulating interleukin-1 receptor antagonist expression. Neuroscience (2005) 132(3):625-31. doi:10.1016/j. neuroscience.2005.01.021

85. Quiniou C, Kooli E, Joyal JS, Sapieha P, Sennlaub F, Lahaie I, et al. Interleukin-1 and ischemic brain injury in the newborn: development of a small molecule inhibitor of IL-1 receptor. Semin Perinatol (2008) 32(5):325-33. doi:10.1053/j. semperi.2008.07.001

86. Wang CH, Wang WT, Cheng SY, Hung WT, Wu TL, Hsueh CM. Leptin and interleukin-1beta modulate neuronal glutamate release and protect against glucose-oxygen-serum deprivation. Curr Neurovasc Res (2010) 7(3):223-37. doi:10.2174/156720210791184925

87. Martin D, Chinookoswong N, Miller G. The interleukin-1 receptor antagonist (rhIL-1ra) protects against cerebral infarction in a rat model of hypoxiaischemia. Exp Neurol (1994) 130(2):362-7. doi:10.1006/exnr.1994.1215

88. Hu X, Nesic-Taylor O, Qiu J, Rea HC, Fabian R, Rassin DK, et al. Activation of nuclear factor-kappaB signaling pathway by interleukin-1 after hypoxia/ischemia in neonatal rat hippocampus and cortex. J Neurochem (2005) 93(1):26-37. doi:10.1111/j.1471-4159.2004.02968.x

89. Campion GV, Lebsack ME, Lookabaugh J, Gordon G, Catalano M. Dose-range and dose-frequency study of recombinant human interleukin-1 receptor antagonist in patients with rheumatoid arthritis. The IL-1Ra Arthritis Study Group. Arthritis Rheum (1996) 39(7):1092-101. doi:10.1002/art.1780390704

90. Nuki G, Bresnihan B, Bear MB, McCabe D. Long-term safety and maintenance of clinical improvement following treatment with anakinra (recombinant human interleukin-1 receptor antagonist) in patients with rheumatoid arthritis: extension phase of a randomized, double-blind, placebo-controlled trial. Arthritis Rheum (2002) 46(11):2838-46. doi:10.1002/art.10578

91. Ferriero DM. Neonatal brain injury. N Engl J Med (2004) 351(19):1985-95. doi:10.1056/NEJMra041996

92. Pierrat V, Haouari N, Liska A, Thomas D, Subtil D, Truffert P. Prevalence, causes, and outcome at 2 years of age of newborn encephalopathy: population based study. Arch Dis Child Fetal Neonatal Ed (2005) 90(3):F257-61. doi:10.1136/adc.2003.047985
93. Graham EM, Ruis KA, Hartman AL, Northington FJ, Fox HE. A systematic review of the role of intrapartum hypoxia-ischemia in the causation of neonatal encephalopathy. Am J Obstet Gynecol (2008) 199(6):587-95. doi:10.1016/j.ajog. 2008.06.094

94. D’Alton ME, Hankins GDV, Berkowitz RL, Bienstock J, Ghidini A, Goldsmith J, et al. Executive summary: neonatal encephalopathy and neurologic outcome, second edition. Report of the American College of Obstetricians and Gynecologists' task force on neonatal encephalopathy. Obstet Gynecol (2014) 123(4):896-901.

95. Edwards AD, Brocklehurst P, Gunn AJ, Halliday H, Juszczak E, Levene M, et al. Neurological outcomes at 18 months of age after moderate hypothermia for perinatal hypoxic ischaemic encephalopathy: synthesis and meta-analysis of trial data. BMJ (2010) 340:c363. doi:10.1136/bmj.c363

96. Fan X, van Bel F, van der Kooij MA, Heijnen CJ, Groenendaal F. Hypothermia and erythropoietin for neuroprotection after neonatal brain damage. Pediatr Res (2013) 73(1):18-23. doi:10.1038/pr.2012.139

97. Fang AY, Gonzalez FF, Sheldon RA, Ferriero DM. Effects of combination therapy using hypothermia and erythropoietin in a rat model of neonatal hypoxiaischemia. Pediatr Res (2013) 73(1):12-7. doi:10.1038/pr.2012.138

Conflict of Interest Statement: The authors declare that the research was conducted in the absence of any commercial or financial relationships that could be construed as a potential conflict of interest.

Received: 23 July 2014; accepted: 23 September 2014; published online: 07 October 2014.

Citation: Rosenzweig JM, Lei J and Burd I (2014) Interleukin-1 receptor blockade in perinatal brain injury. Front. Pediatr. 2:108. doi: 10.3389/fped.2014.00108

This article was submitted to Obstetric and Pediatric Pharmacology, a section of the journal Frontiers in Pediatrics.

Copyright $\odot 2014$ Rosenzweig, Lei and Burd. This is an open-access article distributed under the terms of the Creative Commons Attribution License (CC BY). The use, distribution or reproduction in other forums is permitted, provided the original author(s) or licensor are credited and that the original publication in this journal is cited, in accordance with accepted academic practice. No use, distribution or reproduction is permitted which does not comply with these terms. 